\title{
Baseline Levels of Vitamin D in a Healthy Population from a Region with High Solar Irradiation
}

\author{
Alicia García-Dorta ${ }^{1}$, Lillian Medina-Vega ${ }^{2}$, Jacobo Javier Villacampa-Jiménez ${ }^{2} \oplus$, Marta Hernández-Díaz ${ }^{1}$, \\ Sagrario Bustabad-Reyes ${ }^{1}$, Enrique González-Dávila ${ }^{3}{ }^{1}$ and Federico Díaz-González ${ }^{1,4, *}$ \\ 1 Servicio de Reumatología, Hospital Universitario de Canarias, 38320 La Laguna, Spain; \\ alicia.garcia.dorta@gmail.com (A.G.-D.); martahediaz@gmail.com (M.H.-D.); \\ sagrario.bustabad@gmail.com (S.B.-R.) \\ 2 Servicio de Análisis Clínicos, Hospital Universitario de Canarias, 38320 La Laguna, Spain; \\ lilianmedinatfe@hotmail.com (L.M.-V.); jacobvilla@msn.com (J.J.V.-J.) \\ 3 Departamento de Estadística e Investigación Operativa, Universidad de La Laguna, 38320 La Laguna, Spain; \\ egonzale@ull.edu.es \\ 4 Departamento de Medicina Interna, Dermatología y Psiquiatría, Universidad de La Laguna, \\ 38320 La Laguna, Spain \\ * Correspondence: federico.diaz.gonzalez@gmail.com; Tel.: +34-922678502; Fax: +34-922646792
}

\section{check for} updates

Citation: García-Dorta, A.; Medina-Vega, L.; Villacampa-Jiménez, J.J.; Hernández-Díaz, M.; BustabadReyes, S.; González-Dávila, E.; Díaz-González, F. Baseline Levels of Vitamin D in a Healthy Population from a Region with High Solar Irradiation. Nutrients 2021, 13, 1647. https://doi.org/10.3390/nu13051647

Academic Editors: Alejandro Cifuentes and Alberto Valdés

Received: 7 April 2021

Accepted: 10 May 2021

Published: 13 May 2021

Publisher's Note: MDPI stays neutral with regard to jurisdictional claims in published maps and institutional affiliations.

Copyright: (c) 2021 by the authors. Licensee MDPI, Basel, Switzerland. This article is an open access article distributed under the terms and conditions of the Creative Commons Attribution (CC BY) license (https:/ / creativecommons.org/licenses/by/ $4.0 /)$.

\begin{abstract}
The use of vitamin D (VitD) supplements has become widespread in the last decade due not only to the dissociation between the blood levels recommended as "optimal" and those shown by the healthy population but also to its presumed beneficial effects on multiple disorders. This work evaluated the levels of 25-hydroxyvitamin D $(25(\mathrm{OH}) \mathrm{D})$ in a healthy population of European origin living in a region with high solar irradiation. In serum samples from a population-based study conducted in the Canary Islands, levels of $25(\mathrm{OH}) \mathrm{D}$ were analyzed. In 876 individuals who had no history of kidney or malabsorption disorders and, who had not been treated with calcium and/or VitD supplementation, the median 25(OH)D level was 26.3 (5th; 95th percentile, $14.3 ; 45.8) \mathrm{ng} / \mathrm{mL}$. Notably, $65.4 \%$ of the population had 25(OH)D blood levels below $30 \mathrm{ng} / \mathrm{mL}, 23.4 \%$ below $20 \mathrm{ng} / \mathrm{mL}$ and $6.4 \%$ below $15 \mathrm{ng} / \mathrm{mL}$. Based on the lack of evidence supporting causality between $25(\mathrm{OH}) \mathrm{D}$ levels below what is recommended as optimal ( $\geq 20 \mathrm{ng} / \mathrm{mL}$, or even $\geq 30 \mathrm{ng} / \mathrm{mL}$ ) and major skeletal and non-skeletal diseases, and in light of the distribution of the concentration of this vitamin in healthy adults living under optimal conditions of solar irradiation, it seems reasonable to consider 25(OH)D levels below $20 \mathrm{ng} / \mathrm{mL}$ and close to $15 \mathrm{ng} / \mathrm{mL}$ as adequate for the general population.
\end{abstract}

Keywords: vitamin D levels; population-based distribution; healthy adults; high solar irradiation

\section{Introduction}

Vitamin D (VitD) is a lipid-soluble hormone that plays a key role in phosphorus and calcium metabolism and bone homeostasis [1]. In humans, it is obtained endogenously by the action of ultraviolet radiation (UVR) and exogenously through dietary intake [2,3]. Exogenous sources of VitD3 include certain foods (notably oily fish, such as trout, salmon, and mackerel), by food fortification in the form of dairy products, orange juice or bread [4] or by the medical prescription of supplements. Endogenous synthesis in the skin is usually efficient and represents an easy and reliable way for most people with sufficient sun exposure to attain adequate VitD levels [3]. It has been described that a full day of sun exposure produces 10,000 to 25,000 IU of VitD [5]. Although it depends on age, skin type and color, the area of exposed skin, season and time of day (reviewed in [6,7]), if sun exposure is adequate, then $10 \mathrm{~min}$ of summer sun, without sunscreen, any dietary VitD deficiency is generally less relevant [8]. The form of VitD that circulates in the blood at the highest concentrations and best reflects the overall results of endogenous synthesis and dietary intake is $25(\mathrm{OH}) \mathrm{D}$ [9]. 
It is well established that bone disorders such as rickets and osteomalacia are associated with VitD deficiency [1]. Nonetheless, there is controversy surrounding the optimum levels of this vitamin needed to maintain musculoskeletal health in the adult population [10-14]. Over the last decade, using 25(OH)D supplements has become widespread in Western countries, mainly in response to the observation that basal $25(\mathrm{OH}) \mathrm{D}$ levels in many people in the general population $[15,16]$ fail to reach those proposed as optimal by international guidelines, which recommend a threshold value of $20 \mathrm{ng} / \mathrm{mL}$ [17]. In contrast, others even aim for $\geq 30 \mathrm{ng} / \mathrm{mL}$ [9]. Another factor encouraging using VitD supplementation stems from observational studies that directly correlate VitD levels with a lower risk of developing a wide range of major non-skeletal human conditions, from depression [18] to cancer $[19,20]$, as well as infections [21,22] and cardiovascular events [23]. However, in recent years, randomized controlled studies have progressively downplayed the potential benefits of VitD concerning these [24-30] and other non-skeletal health problems [31,32]. In those studies designed to analyze causality, when the effect of VitD supplementation (versus placebo) was analyzed according to baseline VitD levels, no significant benefits were found in individuals with baseline 25(OH)D levels below $20 \mathrm{ng} / \mathrm{mL}$ [13,14,24,25,27,29,32]. All this evidence strongly suggests that the current VitD levels recommended as optimal for the general population are overestimated.

The primary objective of this study was to assess the distribution of basal $25(\mathrm{OH}) \mathrm{D}$ levels in a healthy population of European origin from an area of year-round sunny warm weather, such as that living in the Canary Islands $\left(28^{\circ} \mathrm{N}\right.$ latitude). The analyses were overall, by seasonality, and stratified by demographic factors (age, gender, and place of residence). Since obesity has been negatively associated with VitD levels $[33,34]$, the body mass index (BMI) was also analyzed. Results obtained under these optimal conditions could help define normal VitD levels according to a healthy population-based distribution.

\section{Materials and Methods}

\subsection{Sample Size and Representativeness}

For calculating the sample size, we initially analyzed 100 random samples from 1240 patients included in EPIRCAN, a multistage population-based study conducted between May 2004 and September 2005 to assess the prevalence of rheumatic diseases among over-20 year-olds living in the Canary Islands (Atlantic islands $28^{\circ} \mathrm{N}, 16^{\circ} \mathrm{W}$ ). Based on the 2005 census of 1,551,000 people over 20 years of age in the Canary Islands [35], and assuming a standard deviation of $11 \mathrm{ng} / \mathrm{mL}$ in line with that in the sample analyzed, a confidence interval of $95 \%$ and a precision in the measurement $25(\mathrm{OH}) \mathrm{D}$ of $0.7 \mathrm{ng} / \mathrm{mL}$, the required sample size was estimated to be 949 individuals. This cohort was selected by stratified sampling as a function of gender, age group (20-44, 45-64 and $\geq 65$ years old), and place of residence (rural/urban) in line with the population distribution there in 2005 according to the Canary Islands Statistics Institute (ISTAC) [35]. Table S1 sets out the number and percentage of individuals in the sample selected for each stratification variable (age, gender, and place of residence). Information on medical history, including former and current medication, was obtained for everyone in this study. Height and weight were measured, and BMI calculated.

\subsection{Study Design}

This was a cross-sectional population-based observational study to assess $25(\mathrm{OH}) \mathrm{D}$ levels in a healthy population of the Canary Islands. Levels of $25(\mathrm{OH}) \mathrm{D}$, calcium and phosphate were measured in 949 blood samples from the EPIRCAN study. A total of 73 individuals $(7.7 \%)$ with a prior history of kidney failure, dialysis, inflammatory bowel disease, malabsorption, osteoporosis, or with a glomerular filtration rate $<60 \mathrm{~mL} / \mathrm{min} / 1.73 \mathrm{~m}^{2}$ were excluded. Patients on bisphosphonate or calcitonin treatment or calcium and/or VitD supplementation were also excluded. The final sample analyzed included 876 healthy individuals (Table 1). The research was carried out in compliance with the Helsinki Declaration. The study protocol was approved by the Institutional Review Committee at Hospital 
Universitario de Canarias (Approval number PIET_13 2004). All subjects included in this study provided informed written consent.

Table 1. Demographic characteristics and levels of VitD, calcium and phosphate in the included (healthy) and excluded individuals.

\begin{tabular}{|c|c|c|c|c|}
\hline & $\begin{array}{c}\text { Healthy Individuals } \\
n=876(92.3 \%)\end{array}$ & $\begin{array}{c}\text { Excluded } \\
n=73(7.7 \%)\end{array}$ & $p$ & $\begin{array}{c}\text { Total } \\
n=949\end{array}$ \\
\hline Sex & & & $<0.001$ & \\
\hline Male & $461(53 \%)$ & $13(18 \%)$ & & $474(50 \%)$ \\
\hline Female & $415(47 \%)$ & $60(82 \%)$ & & $475(50 \%)$ \\
\hline Age (years) & $43.3 \pm 15.8$ & $59.1 \pm 14.9$ & $<0.001$ & $44.5 \pm 16.3$ \\
\hline Age (years) & & & $<0.001$ & \\
\hline $20-44$ & $527(60 \%)$ & $10(14 \%)$ & & $537(57 \%)$ \\
\hline $45-64$ & $233(27 \%)$ & $33(45 \%)$ & & $266(28 \%)$ \\
\hline$\geq 65$ & $116(13 \%)$ & $30(41 \%)$ & & $146(15 \%)$ \\
\hline Area & & & 0.478 & \\
\hline Rural & $134(15 \%)$ & $14(19 \%)$ & & $148(16 \%)$ \\
\hline Urban & $742(85 \%)$ & $59(81 \%)$ & & $801(84 \%)$ \\
\hline $\mathrm{BMI}\left(\mathrm{kg} / \mathrm{m}^{2}\right)$ & $26.74 \pm 4.67$ & $27.79 \pm 4.76$ & 0.070 & $26.82 \pm 4.69$ \\
\hline $25(\mathrm{OH}) \mathrm{D}(\mathrm{ng} / \mathrm{mL})$ & $26.30(14.30 ; 45.84)$ & $23.70(11.50 ; 47.7)$ & 0.351 & $26.20(14.20 ; 45.8)$ \\
\hline Phosphate (mg/dL) & $3.50(2.54 ; 5.25)$ & $3.48(2.35 ; 4.65)$ & 0.425 & $3.50(2.53 ; 5.19)$ \\
\hline Calcium (mg/dL) & $9.34(8.15 ; 10.28)$ & $9.50(8.13 ; 11.12)$ & 0.072 & $9.35(8.15 ; 10.31)$ \\
\hline
\end{tabular}

Data are expressed as $n(\%)$, mean $\pm \mathrm{SD}$ or median $\left(\mathrm{P}_{5} ; \mathrm{P}_{95}\right) .{ }^{*}$ Individuals with a prior history of kidney failure, inflammatory bowel disease, malabsorption, or osteoporosis, or, who had been treated with calcium and or VitD supplements, bisphosphonates or calcitonin, or on dialysis were excluded. BMI: body mass index.

\subsection{Measurement of Blood 25(OH)D Levels}

The blood samples from the participants of the EPIRCAN study were stored at $-80{ }^{\circ} \mathrm{C}$ until use. Levels of $25(\mathrm{OH}) \mathrm{D}$ were measured with a chemiluminescence immunoassay (CLIA) run on an ARCHITECT i1000SR analyzer (Abbott, Chicago, IL, USA), while calcium and phosphate levels were measured by absorbance using the Cobas 702c module (Roche Diagnostics, Basel, Switzerland). To rule out significant degradation of the serum samples during storage, we measured the levels of $25(\mathrm{OH}) \mathrm{D}$ in fresh blood from a group of 100 individuals living in the northern part of the island of Tenerife between 1 August and 31 October 2019, with a sex ratio of 1:1 and an average age of $49.2 \pm 19.6$ years, with no medical history of bone, renal or malabsorptive diseases or 25(OH)D supplementation. The median and 5th; 95th percentiles $\left(\mathrm{P}_{5} ; \mathrm{P}_{95}\right)$ of $25(\mathrm{OH}) \mathrm{D}$ level in this sample was $27.7(12.7$; 42.9) $\mathrm{ng} / \mathrm{mL}$, which was within the range observed in the study population (see below).

\subsection{Statistical Analysis}

Data were stratified by demographic characteristics, comorbidities, and medication use. Continuous variables were described using means and standard deviation or median and percentiles $\mathrm{P}_{5} ; \mathrm{P}_{95}$ when not normally distributed, and categorical variables using the frequency and percentage. Groups were compared using Mann-Whitney U and KruskalWallis tests, or Student's $t$-tests and analysis of variance (ANOVA) for continuous variables and chi-squared tests for categorical variables. A general linear model (ANOVA type II) was used to assess the influence of demographic characteristics on 25(OH)D levels. For $25(\mathrm{OH}) \mathrm{D}$, phosphate and calcium levels, the Kolmogorov-Smirnov test confirmed that the data were not normally distributed and were positively skewed (tail to the right); these problems were resolved by applying a log transformation ( $p$-values $>0.2$ for all sex $*$ age groups). This allowed us to estimate thresholds for VitD that left $(1-\alpha) \%$ of individuals with lower values, by sex * age groups, using the equation Percentile $(1-a) \%=\exp \left(\mu+z_{\alpha} \sigma\right)$, where $\mu$ and $\sigma$ are the mean and standard deviation, respectively, of the log-transformed data (Table S2), $\mathrm{z} \alpha$ is the critical point on the standard normal distribution, for which the righthand tail has an area equal to $\alpha \exp$ is the exponential function. Since ln VitD and BMI 
showed an inverse correlation in patients between 20 and 44 years old (males $r=-0.180$ $p=0.005$ slope $=-0.01615$; females $r=-0.218, p=0.001$, slope $=-0.01698), \mu$ values of VitD for a given BMI different to the mean can be calculated using the formula in Table S2. In the rest of the age groups * sex, there was no significant relationship between $\ln$ VitD and BMI (all $p$-value $>0.253$ ). Similarly, for a given $25(\mathrm{OH}) \mathrm{D}$ level, $\mathrm{x}$, it was possible to obtain the corresponding percentile from the expression $\phi((\operatorname{Ln} x-\mu) / \sigma)$, where $\phi$ is the distribution function of a standardized normal function and $L n$ the natural logarithm. The concordance between percentiles calculated in this way and that of the sample was assessed using Spearman's correlation and the Student's $t$-test of one sample (Table S3). The statistical analysis was carried out using IBM SPSS Statistics for Windows, Version 25.0 (IBM, Armonk, NY, USA) and Microsoft Excel 365.

\section{Results}

\subsection{Study Population}

Table 1 summarizes the demographic characteristics of the individuals excluded $(n=73,7.7 \%)$ and included in the analysis. Of the $876(92.3 \%)$ individuals included, 461 $(53 \%)$ were men and $415(47 \%)$ women, with an overall mean age of $43.3 \pm 15.8$ years old. The BMI of included individuals was $26.7 \pm 4.6 \mathrm{~kg} / \mathrm{m}^{2}$ for the entire population without significant differences between women ( $26.5 \pm 5.2)$ and men (26.9 \pm 4.1$), p=0.23$. Classifying by residence, $134(15 \%)$ lived in rural and $742(85 \%)$ in urban areas. In terms of age, 527 $(60 \%)$ were between 20 and 44 years old, $233(27 \%)$ between 45 and 64 years old, and 116 $(13 \%)$ were 65 years old or more.

\subsection{Levels and Distribution of $25(\mathrm{OH}) D$, Calcium and Phosphate by Gender, Age, Place of Residence and BMI in the Healthy Population}

The median (P5; P95) level of 25(OH)D in the healthy population was $26.3(14.3$; 45.8) $\mathrm{ng} / \mathrm{mL}$, while calcium and phosphate levels were $9.3(8.1 ; 10.2) \mathrm{ng} / \mathrm{dL}$ and $3.5(2.5$; 5.2) ng/dL, respectively (Table 1 ). Analyzing $25(\mathrm{OH}) \mathrm{D}$ levels by gender, age and place of residence, we found significant differences between genders (Table 2, Figure 1A) and age groups (Table 2, Figure 1B), but not by place of residence $(p=0.218)$. Levels of $25(\mathrm{OH}) \mathrm{D}$ correlated inversely with BMI in the entire population $(r=-0.192, p<0.001)$, mainly due to the 20-44 years old group $(\mathrm{r}=-1.90, p<0.001)$.

Table 2. Distribution of the sample of healthy patients by gender and age.

\begin{tabular}{|c|c|c|c|c|c|c|c|c|}
\hline & \multirow{2}{*}{$\begin{array}{c}\text { Male } \\
n=461\end{array}$} & \multirow{2}{*}{$\begin{array}{l}\text { Female } \\
n=415\end{array}$} & \multirow[b]{2}{*}{$p$} & \multicolumn{3}{|c|}{ Age (Years) } & \multirow[b]{2}{*}{$p$} & \multirow{2}{*}{$\begin{array}{c}\text { Total } \\
n=876\end{array}$} \\
\hline & & & & $\begin{array}{c}20-44 \\
n=527\end{array}$ & $\begin{array}{c}45-64 \\
n=233\end{array}$ & $\begin{array}{c}\geq 65 \\
n=116\end{array}$ & & \\
\hline Sex & & & & & & & 0.558 & \\
\hline Male & & & & $271(51 \%)$ & $130(56 \%)$ & $60(52 \%)$ & & $461(53 \%)$ \\
\hline Female & & & & $256(49 \%)$ & $103(44 \%)$ & $56(48 \%)$ & & $415(47 \%)$ \\
\hline Age (years) & $43.9 \pm 15.9$ & $42.7 \pm 15.7$ & 0.259 & & & & & $43.3 \pm 15.8$ \\
\hline Age (years) & & & 0.558 & & & & & \\
\hline $20-44$ & $271(59 \%)$ & $256(62 \%)$ & & & & & & $527(60 \%)$ \\
\hline $45-64$ & $130(28 \%)$ & $103(25 \%)$ & & & & & & $233(27 \%)$ \\
\hline$\geq 65$ & $60(13 \%)$ & $56(13 \%)$ & & & & & & $146(13 \%)$ \\
\hline Area & & & 0.854 & & & & 0.459 & \\
\hline Rural & $72(16 \%)$ & $62(15 \%)$ & & $74(14 \%)$ & $39(16 \%)$ & $21(18 \%)$ & & $134(15 \%)$ \\
\hline Urban & $389(84 \%)$ & $353(85 \%)$ & & $453(86 \%)$ & $194(84 \%)$ & $95(82 \%)$ & & $742(85 \%)$ \\
\hline $\operatorname{BMI}\left(\mathrm{kg} / \mathrm{m}^{2}\right)$ & $26.92 \pm 4.13$ & $26.53 \pm 5.21$ & 0.235 & $25.42 \pm 4.39$ & $28.68 \pm 4.62$ & $28.14 \pm 4.11$ & $<0.001$ & $26.74 \pm 4.67$ \\
\hline $\begin{array}{l}25(\mathrm{OH}) \mathrm{D} \\
\text { (ng/mL) }\end{array}$ & $27.4(15.8 ; 46.7)$ & $25.0(12.8 ; 45.3)$ & $<0.001$ & $27.4(15.6 ; 48.1)$ & $25.0(13.4 ; 43.7)$ & $23.0(12.4 ; 36.6)$ & $<0.001$ & $26.3(14.3 ; 45.8)$ \\
\hline $\begin{array}{l}\text { Phosphate } \\
\text { (mg/dL) }\end{array}$ & $3.48(2.4 ; 4.8)$ & $3.51(2.6 ; 6)$ & 0.180 & $3.58(2.6 ; 5.7)$ & $3.46(2.5 ; 5)$. & $3.23(2.5 ; 4.8)$ & 0.001 & $3.5(2.5 ; 5.2)$ \\
\hline $\begin{array}{l}\text { Calcium } \\
\text { (mg/dL) }\end{array}$ & $9.35(8 . ; 10.3)$ & $9.32(8.2 ; 10.2)$ & 0.584 & $9.36(8.2 ; 10.2)$ & $9.30(8.1 ; 10.4)$ & $9.19(7.9 ; 10.3)$ & 0.031 & $9.3(8.1 ; 10.2)$ \\
\hline
\end{tabular}




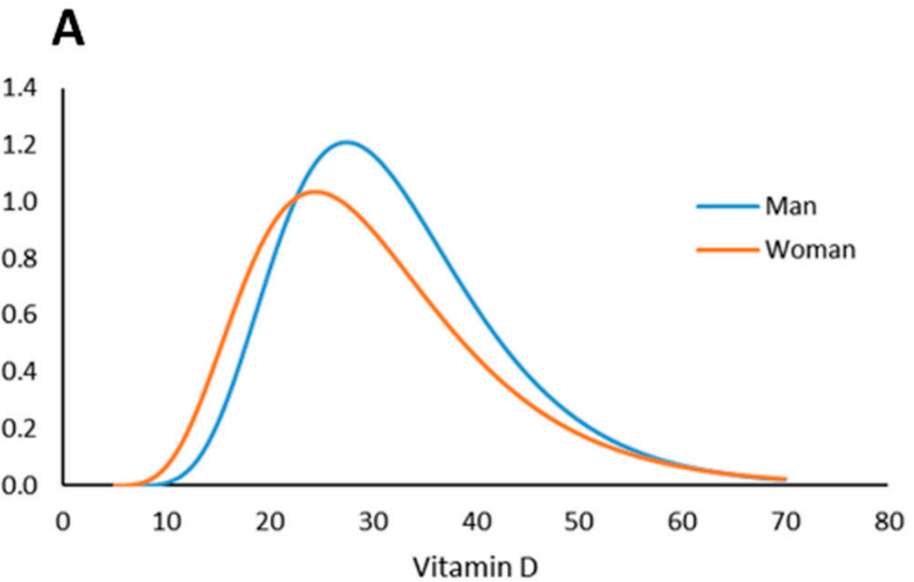

\section{B}

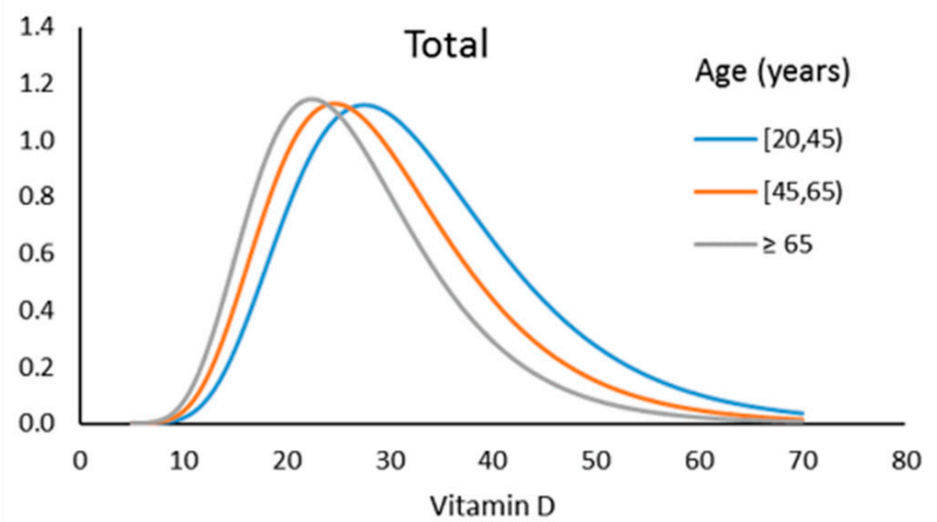

C

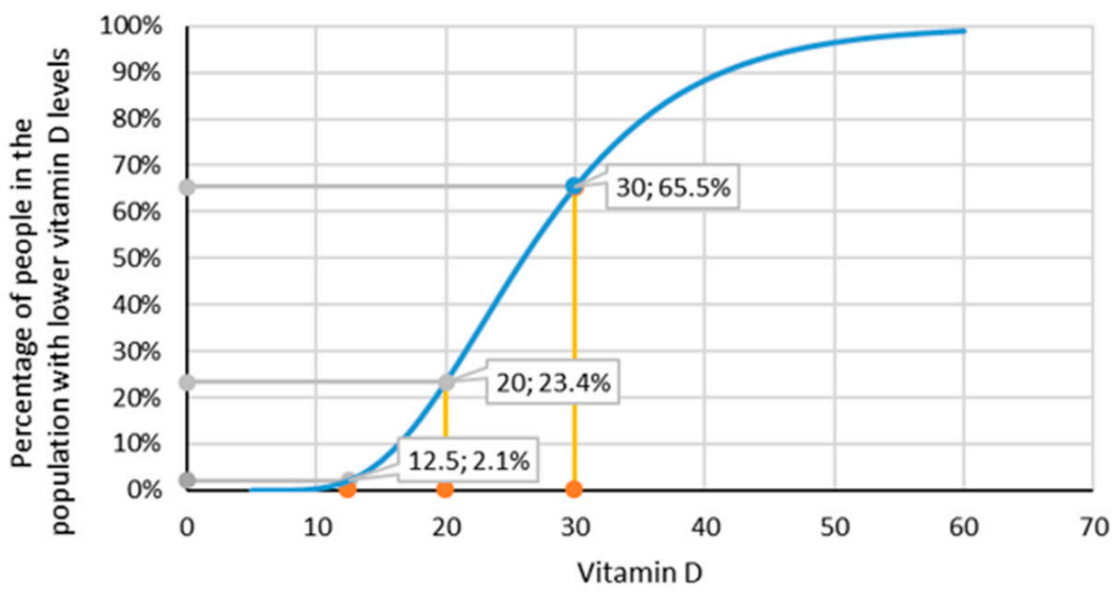

Figure 1. (A) Density function of VitD concentration (ng/mL) by gender. (B) Density function of VitD concentration $(\mathrm{ng} / \mathrm{mL}$ ) by age groups. (C) Distribution of percentiles of VitD concentration.

Table 3 shows that 25(OH)D levels were 2.7 units lower in women than in men $(95 \% \mathrm{CI}$ $-4.1 ;-1.4, p<0.001)$ and 4.4 units higher in 20 to 44 year-olds $(95 \%$ CI, $2.3 ; 6.5, p<0.001)$ and 2.5 units higher in 45 to 64 year-olds (95\% CI $0.4 ; 4.6, p<0.019)$ than in the oldest age group ( $\geq 65$ years). VitD levels decreased by $0.298 \mathrm{ng} / \mathrm{mL}(95 \% \mathrm{CI},-0.45 ;-0.15, p<0.001)$ for each unit of increase in BMI. 
Table 3. General linear model for VitD level concerning the demographic factors considered.

\begin{tabular}{cccccc}
\hline Parameter & Coefficient & SE & Student's $t$ & $p$ & 95\% CI \\
\hline Intersection & 33.607 & 2.326 & 14.447 & $<0.001$ & $(29.041 ; 38.174)$ \\
\hline Age $($ ref $\geq 65)$ & & & & & \\
$20-44$ & 4.372 & 1.045 & 4.183 & $<0.001$ & $(2.320 ; 6.424)$ \\
$45-64$ & 2.483 & 1.056 & 2.350 & 0.019 & $(0.409 ; 4.557)$ \\
Female sex & -2.689 & 0.719 & -3.742 & $<0.001$ & $(-4.099 ;-1.278)$ \\
Rural area & -1.438 & 1.166 & -1.234 & 0.218 & $(-3.727 ; 0.850)$ \\
BMI $\left(\mathrm{kg} / \mathrm{m}^{2}\right)$ & -0.298 & 0.075 & -3.969 & $<0.001$ & $(-0.446 ;-0.151)$ \\
\hline
\end{tabular}

BMI: body mass index; SE: standard error; $95 \%$ CI: $95 \%$ confidence interval.

VitD levels obtained after applying a log transformation were normally distributed by sex * age groups, and the percentiles calculated by this transformation and those of the sample only presented slight deviations (Table S3). This allowed us to determine the percentage of the population with 25(OH)D levels below certain thresholds; Table 4 shows these threshold percentages ranging from 12 to $30 \mathrm{ng} / \mathrm{mL}$, both overall and stratified by age or sex. The 20-44 age group shows the percentiles considering the mean BMI for women (24.92) and men (25.89). For other BMIs, the values can be calculated using the formula in Table 3. Notably, $65.5 \%$ of the population had $25(\mathrm{OH}) \mathrm{D}$ levels under $30 \mathrm{ng} / \mathrm{mL}$, while $23.4 \%, 6.4 \%$ and $2 \%$ of the population had levels below 20,15 and $12.5 \mathrm{ng} / \mathrm{mL}$, respectively.

Table 4. Percentage of healthy individuals (percentile) with $25(\mathrm{OH}) \mathrm{D}$ levels below the values in the first column.

\begin{tabular}{|c|c|c|c|c|c|c|c|c|c|c|c|c|}
\hline \multirow{2}{*}{$\begin{array}{c}\text { Baseline } \\
25(\mathrm{OH}) \mathrm{D} \\
(\mathrm{ng} / \mathrm{mL})\end{array}$} & \multicolumn{3}{|c|}{$\begin{array}{c}\text { Male } \\
\text { (Age, Years) }\end{array}$} & \multicolumn{3}{|c|}{$\begin{array}{c}\text { Female } \\
\text { (Age, Years) }\end{array}$} & \multicolumn{2}{|c|}{ Gender } & \multicolumn{3}{|c|}{ Age (Years) } & \multirow{2}{*}{ Total } \\
\hline & $20-44$ * & 45-64 & $\geq 65$ & $20-44$ * & $45-64$ & $\geq 65$ & Male & Female & $20-44 *$ & $45-64$ & $\geq 65$ & \\
\hline 12 & $0.3 \%$ & $1.3 \%$ & $0.8 \%$ & $2.1 \%$ & $3.2 \%$ & $7.4 \%$ & $0.6 \%$ & $3.2 \%$ & $1.0 \%$ & $2.1 \%$ & $3.6 \%$ & $1.6 \%$ \\
\hline 13 & $0.6 \%$ & $2.3 \%$ & $1.6 \%$ & $3.4 \%$ & $5.2 \%$ & $11.2 \%$ & $1.1 \%$ & $5.0 \%$ & $1.7 \%$ & $3.5 \%$ & $5.8 \%$ & $2.7 \%$ \\
\hline 14 & $1.2 \%$ & $3.7 \%$ & $2.9 \%$ & $5.2 \%$ & $7.9 \%$ & $15.8 \%$ & $2.0 \%$ & $7.3 \%$ & $2.9 \%$ & $5.5 \%$ & $8.8 \%$ & $4.3 \%$ \\
\hline 15 & $2.0 \%$ & $5.6 \%$ & $4.7 \%$ & $7.4 \%$ & $11.2 \%$ & $21.1 \%$ & $3.3 \%$ & $10.2 \%$ & $4.4 \%$ & $8.0 \%$ & $12.4 \%$ & $6.4 \%$ \\
\hline 16 & $3.2 \%$ & $8.1 \%$ & $7.2 \%$ & $10.0 \%$ & $15.0 \%$ & $26.8 \%$ & $5.0 \%$ & $13.5 \%$ & $6.4 \%$ & $11.1 \%$ & $16.5 \%$ & $8.9 \%$ \\
\hline 17 & $4.8 \%$ & $11.1 \%$ & $10.3 \%$ & $13.1 \%$ & $19.4 \%$ & $32.9 \%$ & $7.2 \%$ & $17.2 \%$ & $8.8 \%$ & $14.7 \%$ & $21.2 \%$ & $12.0 \%$ \\
\hline 18 & $6.9 \%$ & $14.6 \%$ & $14.0 \%$ & $16.5 \%$ & $24.1 \%$ & $39.0 \%$ & $9.9 \%$ & $21.3 \%$ & $11.6 \%$ & $18.8 \%$ & $26.3 \%$ & $15.4 \%$ \\
\hline 19 & $9.5 \%$ & $18.4 \%$ & $18.2 \%$ & $20.2 \%$ & $29.1 \%$ & $45.1 \%$ & $13.1 \%$ & $25.6 \%$ & $14.9 \%$ & $23.2 \%$ & $31.6 \%$ & $19.3 \%$ \\
\hline 20 & $12.5 \%$ & $22.7 \%$ & $22.9 \%$ & $24.2 \%$ & $34.3 \%$ & $51.0 \%$ & $16.7 \%$ & $30.1 \%$ & $18.5 \%$ & $27.8 \%$ & $37.0 \%$ & $23.4 \%$ \\
\hline 21 & $16.0 \%$ & $27.2 \%$ & $28.0 \%$ & $28.3 \%$ & $39.5 \%$ & $56.5 \%$ & $20.7 \%$ & $34.6 \%$ & $22.4 \%$ & $32.7 \%$ & $42.4 \%$ & $27.7 \%$ \\
\hline 22 & $19.8 \%$ & $31.8 \%$ & $33.2 \%$ & $32.5 \%$ & $44.6 \%$ & $61.7 \%$ & $25.0 \%$ & $39.2 \%$ & $26.5 \%$ & $37.5 \%$ & $47.7 \%$ & $32.2 \%$ \\
\hline 23 & $23.9 \%$ & $36.6 \%$ & $38.6 \%$ & $36.8 \%$ & $49.6 \%$ & $66.5 \%$ & $29.5 \%$ & $43.7 \%$ & $30.7 \%$ & $42.4 \%$ & $52.8 \%$ & $36.7 \%$ \\
\hline 24 & $28.2 \%$ & $41.3 \%$ & $43.9 \%$ & $41.0 \%$ & $54.4 \%$ & $70.8 \%$ & $34.1 \%$ & $48.1 \%$ & $35.1 \%$ & $47.2 \%$ & $57.6 \%$ & $41.3 \%$ \\
\hline 25 & $32.7 \%$ & $46.0 \%$ & $49.2 \%$ & $45.2 \%$ & $58.9 \%$ & $74.7 \%$ & $38.7 \%$ & $52.3 \%$ & $39.4 \%$ & $51.8 \%$ & $62.2 \%$ & $45.7 \%$ \\
\hline 26 & $37.3 \%$ & $50.5 \%$ & $54.2 \%$ & $49.2 \%$ & $63.1 \%$ & $78.2 \%$ & $43.4 \%$ & $56.4 \%$ & $43.7 \%$ & $56.2 \%$ & $66.4 \%$ & $50.0 \%$ \\
\hline 27 & $41.9 \%$ & $54.9 \%$ & $59.0 \%$ & $53.2 \%$ & $67.1 \%$ & $81.3 \%$ & $47.9 \%$ & $60.2 \%$ & $47.9 \%$ & $60.4 \%$ & $70.2 \%$ & $54.2 \%$ \\
\hline 28 & $46.4 \%$ & $59.0 \%$ & $63.5 \%$ & $56.9 \%$ & $70.7 \%$ & $83.9 \%$ & $52.3 \%$ & $63.8 \%$ & $52.0 \%$ & $64.3 \%$ & $73.7 \%$ & $58.2 \%$ \\
\hline 29 & $50.8 \%$ & $62.9 \%$ & $67.7 \%$ & $60.4 \%$ & $74.0 \%$ & $86.3 \%$ & $56.6 \%$ & $67.1 \%$ & $55.9 \%$ & $67.9 \%$ & $76.9 \%$ & $61.9 \%$ \\
\hline 30 & $55.0 \%$ & $66.6 \%$ & $71.5 \%$ & $63.8 \%$ & $77.0 \%$ & $88.3 \%$ & $60.6 \%$ & $70.3 \%$ & $59.7 \%$ & $71.3 \%$ & $79.8 \%$ & $65.5 \%$ \\
\hline
\end{tabular}

* Values for mean BMI of 24.92 for females and 25.89 for males.

Figure $1 \mathrm{C}$ shows the distribution of $25(\mathrm{OH}) \mathrm{D}$ levels in the overall sample analyzed.

\subsection{Seasonal Variation in Serum $25(\mathrm{OH}) \mathrm{D}$}

During the study, the mean total solar irradiation increased from $4.21 \pm 0.67 \mathrm{kWh} / \mathrm{m}^{2} /$ day during the October to March period to $6.36 \pm 0.43 \mathrm{kWh} / \mathrm{m}^{2} /$ day between April to September [36] and positively correlated with serum a $25(\mathrm{OH}) \mathrm{D}$ increment of $2.01 \mathrm{ng} / \mathrm{mL}(95 \%$ IC: $0.73-3.30, p=0.002)$. Average concentrations of $25(\mathrm{OH}) \mathrm{D}$ showed large variations over the different months of the year (Table 5 and Figure 2) with a profile that replicated the shape of the curve of total solar irradiation with a delay of 2 months (Figure 2). The mean serum concentration of $25(\mathrm{OH}) \mathrm{D}$ was $44 \%$ higher in September $(30.51 \pm 10.25 \mathrm{ng} / \mathrm{mL})$ than in March $(21.78 \pm 8.21 \mathrm{ng} / \mathrm{mL} ; p<0.0001)$. During the third quarter of the year (July to September), the median serum concentration of 25(OH)D, 28.1 (P5-P95:15.5; 52.2) ng/mL was $28 \%$ higher than during the first quarter (January-March), 22.0 (P5-P95:10.0; 36.9) 
$\mathrm{ng} / \mathrm{mL}, p<0.001)$. During the first quarter of the year (January-March), $12.3 \%(23 / 187)$ of patients had serum concentrations of $25(\mathrm{OH}) \mathrm{D}$ lower than $15 \mathrm{ng} / \mathrm{mL}, 38.0 \%(70 / 187)$ lower than $20 \mathrm{ng} / \mathrm{mL}$, and $78.6 \%(145 / 187)$ had levels lower than $30 \mathrm{ng} / \mathrm{mL}$, compared with the third quarter of the year (July-September), when $4.6 \%(8 / 175)$ had levels below $15 \mathrm{ng} / \mathrm{mL}, 9.7 \%$ (17/175) below $20 \mathrm{ng} / \mathrm{mL}$, and 54.9\% (94/175) leveled below $30 \mathrm{ng} / \mathrm{mL}$, $p<0.001$ (Table 5).

Table 5. Serum levels of 25(OH)D during the different quarters of the year.

\begin{tabular}{|c|c|c|c|c|c|c|}
\hline $\begin{array}{l}\text { Quarters } \\
\text { Months }\end{array}$ & $\begin{array}{c}\text { Number of } \\
\text { Subjects }\end{array}$ & $25(\mathrm{OH}) \mathrm{D} \mathrm{ng} / \mathrm{mL}$ & 25(OH)D ng/mL & $25(\mathrm{OH}) \mathrm{D} \leq 15 \mathrm{ng} / \mathrm{mL}$ & $25(\mathrm{OH}) \mathrm{D} \leq 20 \mathrm{ng} / \mathrm{mL}$ & $25(\mathrm{OH}) \mathrm{D} \leq 30 \mathrm{ng} / \mathrm{mL}$ \\
\hline $\begin{array}{c}\mathrm{Q} 1 \\
\text { January-March }\end{array}$ & 187 & $23.1 \pm 8.4$ & $22.0(10.0 ; 37.0)$ & $23(12.3 \%)$ & $71(38.0 \%)$ & $147(78.6 \%)$ \\
\hline $\begin{array}{c}\text { Q2 } \\
\text { April-June }\end{array}$ & 275 & $27.0 \pm 9.1$ & $25.4(14.0 ; 44.0)$ & $14(5.1 \%)$ & $67(24.4 \%)$ & $183(66.5 \%)$ \\
\hline $\begin{array}{c}\text { Q3 } \\
\text { July-September }\end{array}$ & 175 & $31.1 \pm 10.4$ & $28.1(15.3 ; 52.2)$ & $8(4.6 \%)$ & $17(9.7 \%)$ & $96(54.9 \%)$ \\
\hline $\begin{array}{c}\text { Q4 } \\
\text { October-December }\end{array}$ & 239 & $28.8 \pm 10.6$ & $27.5(15.3 ; 47.6)$ & $10(4.2 \%)$ & $39(22.1 \%)$ & $144(60.3 \%)$ \\
\hline All & 876 & $27.6 \pm 10.0$ & $26.3(14.3 ; 45.8)$ & $55(6.3 \%)$ & $194(22.1 \%)$ & $570(65.1 \%)$ \\
\hline
\end{tabular}

Data expressed as mean $\pm \mathrm{SD}$, median $\left(\mathrm{P}_{5} ; \mathrm{P}_{95}\right)$ or $n(\%)$.

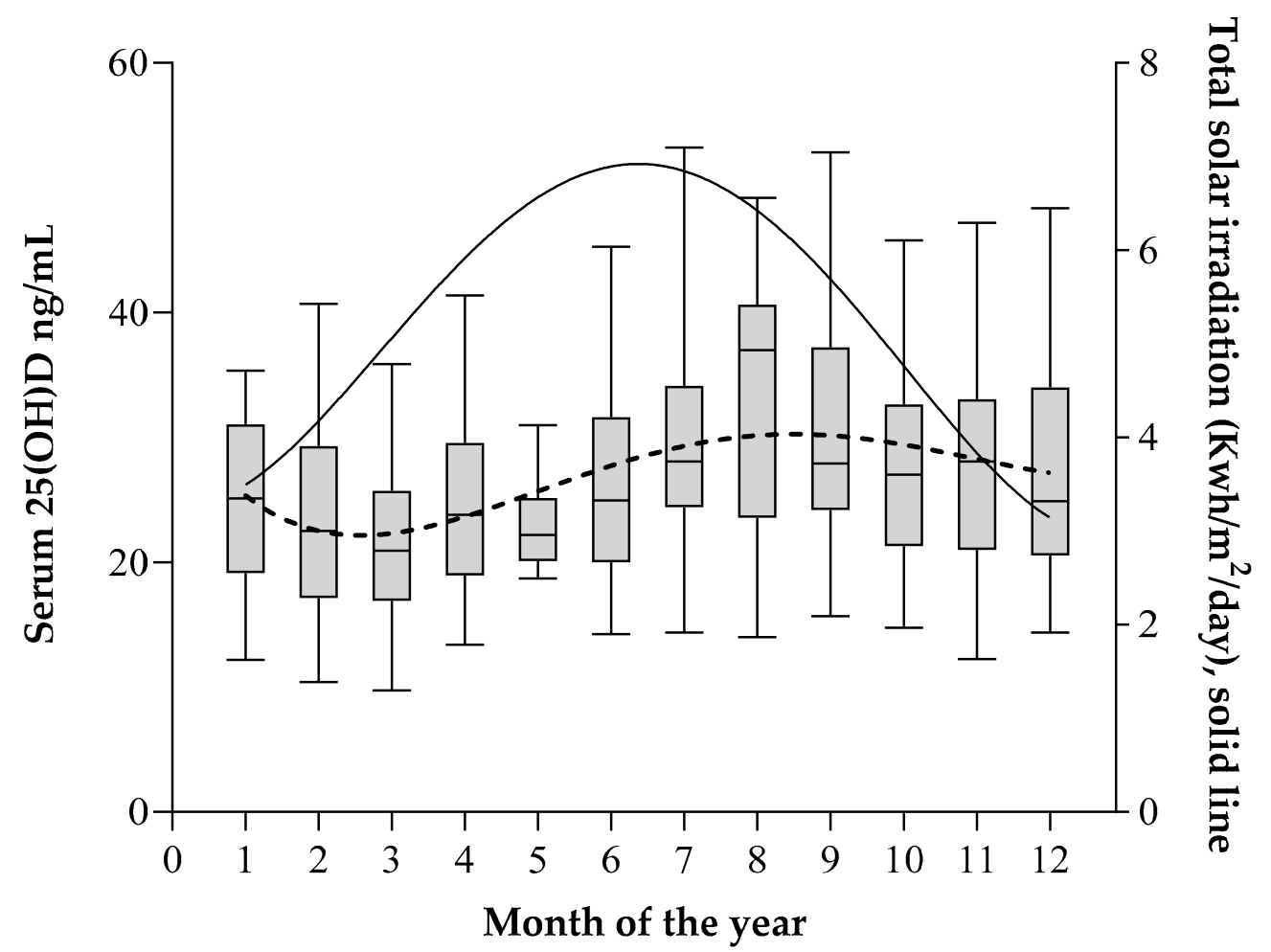

Figure 2. Box plot graph showing the serum 25(OH)D levels during the different months of the year. The values represent medians (horizontal line), interquartile ranges (box) and P5 and P95 percentile (whiskers). The solid line represents the variation of mean total solar irradiation in the Canary Islands during the time frame of the study.

\section{Discussion}

The most relevant findings in this study can be summarized as follows: (1) a healthy population of European origin living in an area with high levels of solar radiation and not taking VitD supplements had a median 25(OH)D level of $26 \mathrm{ng} / \mathrm{mL}$; and (2) based on the population distribution, $65.5 \%$ of the healthy individuals had $25(\mathrm{OH}) \mathrm{D}$ levels below $30 \mathrm{ng} / \mathrm{mL}, 23.4 \%$ below $20 \mathrm{ng} / \mathrm{mL}$ and $5 \%$ levels below $14.3 \mathrm{ng} / \mathrm{mL}$. Given that these VitD population distribution data were collected under optimal conditions, together with the absence of studies demonstrating any causal relationship between vitamin D levels $(<20$ 
vs. $\geq 20 \mathrm{ng} / \mathrm{mL}$ ) and certain skeletal and extraskeletal pathological conditions, it seems reasonable to consider 25(OH)D levels below $20 \mathrm{ng} / \mathrm{mL}$ and very close to $15 \mathrm{ng} / \mathrm{mL}$ as adequate for healthy adult populations. We believe that a downward readjustment of the recommended "optimal" VitD levels for healthy populations to these proposed new limits will have important implications not only for healthcare costs [37], and safety [38-40], avoiding over diagnosed and overtreated for a VitD "deficiency", but also for the design of trials examining the benefits of VitD supplementation in human diseases.

Studies in the United States of America, France and China have found 25(OH)D levels $<30 \mathrm{ng} / \mathrm{mL}$ in $75 \%$ [15], 80\% [16] and 83\% [41] of the population, respectively, figures that are overall higher than those in our study $(65.5 \%)$. This could be explained by differences between ethnic groups and/or levels of local solar irradiation. Genetic studies of the current population of the Canary Islands have shown that $90 \%$ of the paternal lineage is of European origin [42]. Sunlight exposure is key to synthesize VitD [3]. Exposure of the face and arms to 3-7 min of sunlight each day in areas with solar radiation of $1.8 \mathrm{kWh} / \mathrm{m}^{2} /$ day in the summer months allows synthesizing 400 to 1000 IUs of VitD, equivalent to the recommended daily dose of this vitamin [43]. In this regard, several studies on the effect of solar irradiation on $25(\mathrm{OH}) \mathrm{D}$ production in Europeans have been performed in the Canary Islands [44,45]. Between 1983 and 2005, the Canary Islands had a mean daily solar radiation level of $5.23 \mathrm{kWh} / \mathrm{m}^{2} /$ day, much higher than that of European cities, such as London $\left(2.88 \mathrm{kWh} / \mathrm{m}^{2} /\right.$ day), Paris $\left(3.25 \mathrm{kWh} / \mathrm{m}^{2} /\right.$ day) or Rome $\left(4.5 \mathrm{kWh} / \mathrm{m}^{2} /\right.$ day) [36]. In our population-based study, VitD levels varied seasonally following changes in solar irradiation, with a time lag of approximately 2 months, in a range like previously observed [46]. The percentage of individuals with VitD levels below $15 \mathrm{ng} / \mathrm{mL}$ remained stable at around 5\% throughout the year, except during the first quarter (January-March), when this percentage reached $12 \%$ of the population.

While there is consensus on the levels of $25(\mathrm{OH}) \mathrm{D}$ that define clinical deficiency $(<4 \mathrm{ng} / \mathrm{mL})$, there is no agreement on the optimal levels of this prehormone in the general population [47]. In 2003, the World Health Organization defined VitD deficiency as 25(OH)D levels below $10 \mathrm{ng} / \mathrm{mL}$ and insufficiency as levels below $20 \mathrm{ng} / \mathrm{mL}$ [48]. Since then, however, other reference ranges have been established $[9,17]$, and in the last 10 years, most clinical laboratories have recommended that the general population aim for levels above $30 \mathrm{ng} / \mathrm{mL}$. The rationale for establishing this limit was based on reports that $25(\mathrm{OH}) \mathrm{D}$ levels below $30 \mathrm{ng} / \mathrm{mL}$ were associated with increases in parathyroid hormone [49-51]. However, there is evidence suggesting that the relationship between parathyroid hormone and $25(\mathrm{OH}) \mathrm{D}$ is inconsistent, and there is no absolute threshold level of serum $25(\mathrm{OH}) \mathrm{D}$ at which PTH levels rise [50,51], and hence, should not be used as the basis for determining optimal VitD levels in the general population [17].

Regarding the role of VitD in skeletal health, it has been suggested that $25(\mathrm{OH}) \mathrm{D}$ levels $>12.5 \mathrm{ng} / \mathrm{mL}$ are sufficient for maintaining good musculoskeletal health in middle-aged women [52]. In this context, an ancillary study of the VITAL trial, which randomized almost 26,000 men and women older than 50 years to 2000 IU of VitD or placebo, included a subcohort of 687 participants older than 50 years whose bone mineral density (BMD) at the spine, hip, and whole-body were assessed at baseline and over a 2 year period. Results showed no effect on BMD after 2 years of VitD supplementation either in the whole population or in subgroups defined by baseline $25(\mathrm{OH}) \mathrm{D}$ levels $<15 \mathrm{ng} / \mathrm{mL}$ vs. $>15 \mathrm{ng} / \mathrm{mL}$ or even at $<10 \mathrm{ng} / \mathrm{mL}$ vs. $>10 \mathrm{ng} / \mathrm{mL}$ [14]. Similar negative results regarding the benefit of VitD supplementation (in the entire population or in the same subgroups of baseline $25(\mathrm{OH}) \mathrm{D})$ in the risk of falls were provided by the VITAL trial [53]. The role of VitD supplementation on non-vertebral fractures and falls was analyzed both as secondary and post hoc outcomes in the VIDA trial, a randomized placebo-controlled study that included more than 5000 men and women older than 50 years [54]. After a mean of 3.4 years of follow-up, the study concluded that VitD supplementation did not prevent falls or fractures in healthy adult populations. Interestingly, when the analysis was performed 
in subgroups defined by $25(\mathrm{OH}) \mathrm{D}$ at baseline, VitD supplementation in individuals with less than $10 \mathrm{ng} / \mathrm{mL}$ of $25(\mathrm{OH}) \mathrm{D}$ levels did not result in reduced fracture risk [13].

Defining the threshold of normality for VitD has key implications not only for healthcare costs [37] —i.e., avoiding unnecessary VitD screening and supplementation [55]—but also for the proper design of clinical trials to evaluate the impact of VitD supplementation on different humans diseases. A recent randomized clinical trial on type 2 diabetes [56] prevention illustrated this latter topic very well. The results showed that VitD supplementation does not affect preventing type 2 diabetes. Baseline 25(OH)D levels of the patients included clearly exceeded the $20 \mathrm{ng} / \mathrm{mL}$ threshold: $28.2 \mathrm{ng} / \mathrm{mL}$. A relevant conclusion of this work is that VitD supplementation in already repleted patients does not affect type 2 diabetes prevention. A post hoc analysis of this study showed that only those individuals with a baseline $25(\mathrm{OH}) \mathrm{D}$ level $<12 \mathrm{ng} / \mathrm{mL}$ benefited from VitD supplementation [56]. Studying the effects of VitD only in deficient subjects greatly increases the likelihood of showing a benefit from supplementation since the effect of a threshold nutrient is not likely to emerge if both the control and supplementation groups have sufficient levels of $25(\mathrm{OH}) \mathrm{D}$ at baseline [47].

Regarding gender differences, in our study, 25(OH)D levels were significantly higher in men than in women. Similar patterns have been found in Greek schoolchildren [57] and in a Chinese adult population [41]. Concerning age, our results indicate a significant trend towards decreases in $25(\mathrm{OH}) \mathrm{D}$ levels with age, in line with previous reports $[58,59]$. The inverse association between $25(\mathrm{OH}) \mathrm{D}$ levels and $\mathrm{BMI}$ found in this study is supported by previous studies [33,34].

Our study has certain strengths and weaknesses regarding its objective to assess the population distribution of basal $25(\mathrm{OH}) \mathrm{D}$ levels: (1) this is a healthy population-based study based on a healthy population with sufficient power for determining the levels of this vitamin to within $0.7 \mathrm{ng} / \mathrm{mL}$; (2) measurements were made on a representative sample of residents in the Canary Islands, people of European origin, who enjoy high levels of solar irradiation; (3) in our study we have proactively ruled out interference from VitD supplementation, the most potent source of $25(\mathrm{OH}) \mathrm{D}$, and samples were obtained 15 years ago were VitD food fortification was less common; (4) 25(OH)D levels were determined using an automated CLIA, a cost-effective and time-efficient method [60], but less accurate and reproducible than liquid chromatography-tandem mass spectrometry (LC-MS/MS), the best method to quantify VitD [61]; and (5) although clothing in the Canary Islands commonly leaves the arms uncovered and that the most frequent skin phototypes are II-IV, being the III the most common, these and other parameters with a smaller impact on 25(OH)D levels than VitD supplementation, such as using sunscreens or time outdoors, were not considered in this work.

\section{Conclusions}

Given the evidence supporting that VitD supplementation in adult individuals with baseline $25(\mathrm{OH}) \mathrm{D}$ levels $<15 \mathrm{ng} / \mathrm{mL}$ does not result in improved musculoskeletal health $[13,14,53]$, and the fact that a causal relationship of VitD with numerous non-skeletal diseases has not yet been demonstrated [24,25,31,62], and in light of the distribution of the concentration of this vitamin in healthy adults living under optimal conditions of solar irradiation, it seems reasonable to consider $25(\mathrm{OH})$ D levels below $20 \mathrm{ng} / \mathrm{mL}$ and close to $15 \mathrm{ng} / \mathrm{mL}$ as optimal, at least for the general population of European origin.

Supplementary Materials: The following are available online at https:/ /www.mdpi.com/article/10 $.3390 /$ nu13051647/s1, Table S1. Distribution of the study population by place of residence, gender, and age, Table S2. Means $(\mu)$ and standard deviations $(\sigma)$ of log-transformed VitD levels, Table S3. Difference between percentiles obtained from sample data and those obtained by applying the condition of normality on the log transformation.

Author Contributions: Conceptualization, A.G.-D., S.B.-R. and F.D.-G.; methodology, L.M.-V., J.J.V.J., M.H.-D. and A.G.-D.; formal analysis, E.G.-D. and F.D.-G.; writing—original draft preparation, 
A.G.-D.; writing-review and editing, F.D.-G.; funding acquisition, F.D.-G. and S.B.-R. All authors have read and agreed to the published version of the manuscript.

Funding: This work was supported by a grant from the Spanish Ministry of Health, and by Fondo Europeo de Desarrollo Regional (FEDER) (PI15/01810 to F. D-G). This project was also supported by the Asociación para la Ayuda a la Investigación del Hospital Universitario de Canarias (REUNINVES).

Institutional Review Board Statement: The study was conducted according to the guidelines of the Declaration of Helsinki and approved by the Institutional Review Committee at Hospital Universitario de Canarias (Approval number PIET_13 2004).

Informed Consent Statement: Informed consent was obtained from all subjects involved in the study.

Data Availability Statement: The datasets generated and/or analyzed during the current study are available from the corresponding authors upon reasonable request.

Acknowledgments: For the invaluable help with the collection and processing of the population samples for this study, the authors are grateful to the members of the Rheumatology Services of the following hospitals: Hospital Universitario de Canarias, Juan Betencourt Baute and Vanesa Hernández-Hernández; Hospital Universitario Nuestra Señora de La Candelaria, Fátima Álvarez, Arancha Arteaga and Cristina Luna; Hospital Insular Materno-Infantil de Las Palmas de Gran Canaria, Sergio Machín; and Hospital General de La Palma, Alberto Alvarez-Pio.

Conflicts of Interest: The authors declare no conflict of interest. The funders had no role in the design of the study; in the collection, analyses, or interpretation of data; in the writing of the manuscript, or in the decision to publish the results.

\section{References}

1. Jones, G. Vitamin D. In Modern Nutrition in Health and Disease, 11th ed.; Ross, A.C., Caballero, B., Cousins, R.J., Tucker, K.L., Ziegler, T.R., Eds.; Lippincott Williams and Wilkins: Philadelphia, PA, USA, 2014.

2. Holick, M.F. Vitamin D deficiency. N. Engl. J. Med. 2007, 357, 266-281. [CrossRef]

3. Engelsen, O. The relationship between ultraviolet radiation exposure and vitamin D status. Nutrients 2010, 2, 482-495. [CrossRef] [PubMed]

4. Calvo, M.S.; Whiting, S.J.; Barton, C.N. Vitamin D fortification in the United States and Canada: Current status and data needs. Am. J. Clin. Nutr. 2004, 80, 1710S-1716S. [CrossRef]

5. Holick, M.F. Vitamin D: A d-lightful solution for health. J. Investig. Med. 2011, 59, 872-880. [CrossRef] [PubMed]

6. Holick, M.F. Environmental factors that influence the cutaneous production of vitamin D. Am. J. Clin. Nutr. 1995, 61, 638S-645S. [CrossRef]

7. Webb, A.R. Who, what, where and when-influences on cutaneous vitamin D synthesis. Prog. Biophys. Mol. Biol. 2006, 92, 17-25. [CrossRef]

8. Webb, A.R.; Engelsen, O. Ultraviolet exposure scenarios: Risks of erythema from recommendations on cutaneous vitamin D synthesis. Adv. Exp. Med. Biol. 2008, 624, 72-85. [CrossRef]

9. Holick, M.F.; Binkley, N.C.; Bischoff-Ferrari, H.A.; Gordon, C.M.; Hanley, D.A.; Heaney, R.P.; Murad, M.H.; Weaver, C.M.; Endocrine, S. Evaluation, treatment, and prevention of vitamin D deficiency: An endocrine society clinical practice guideline. J. Clin. Endocrinol. Metab. 2011, 96, 1911-1930. [CrossRef]

10. Giustina, A.; Adler, R.A.; Binkley, N.; Bouillon, R.; Ebeling, P.R.; Lazaretti-Castro, M.; Marcocci, C.; Rizzoli, R.; Sempos, C.T.; Bilezikian, J.P. Controversies in vitamin D: Summary statement from an international conference. J. Clin. Endocrinol. Metab. 2019, 104, 234-240. [CrossRef]

11. Trajanoska, K.; Morris, J.A.; Oei, L.; Zheng, H.F.; Evans, D.M.; Kiel, D.P.; Ohlsson, C.; Richards, J.B.; Rivadeneira, F.; Consortium, G.G.; et al. Assessment of the genetic and clinical determinants of fracture risk: Genome wide association and mendelian randomisation study. BMJ 2018, 362, k3225. [CrossRef] [PubMed]

12. Zhao, J.G.; Zeng, X.T.; Wang, J.; Liu, L. Association between calcium or vitamin D supplementation and fracture incidence in community-dwelling older adults: A systematic review and meta-analysis. JAMA 2017, 318, 2466-2482. [CrossRef]

13. Khaw, K.T.; Stewart, A.W.; Waayer, D.; Lawes, C.M.M.; Toop, L.; Camargo, C.A., Jr.; Scragg, R. Effect of monthly high-dose vitamin D supplementation on falls and non-vertebral fractures: Secondary and post-hoc outcomes from the randomised, double-blind, placebo-controlled ViDA trial. Lancet Diabetes Endocrinol. 2017, 5, 438-447. [CrossRef]

14. LeBoff, M.S.; Chou, S.H.; Murata, E.M.; Donlon, C.M.; Cook, N.R.; Mora, S.; Lee, I.M.; Kotler, G.; Bubes, V.; Buring, J.E.; et al. Effects of supplemental vitamin D on bone health outcomes in women and men in the VITamin D and OmegA-3 TriaL (VITAL). J. Bone Miner. Res. 2020, 35, 883-893. [CrossRef]

15. Medicine, I.O. Dietary Reference Intakes for Calcium and Vitamin D; The National Academies Press: Washington, DC, USA, 2011; p. 1132. 
16. Souberbielle, J.C.; Massart, C.; Brailly-Tabard, S.; Cavalier, E.; Chanson, P. Prevalence and determinants of vitamin D deficiency in healthy French adults: The VARIETE study. Endocrine 2016, 53, 543-550. [CrossRef] [PubMed]

17. Ross, A.C.; Manson, J.E.; Abrams, S.A.; Aloia, J.F.; Brannon, P.M.; Clinton, S.K.; Durazo-Arvizu, R.A.; Gallagher, J.C.; Gallo, R.L.; Jones, G.; et al. The 2011 report on dietary reference intakes for calcium and vitamin D from the institute of medicine: What clinicians need to know. J. Clin. Endocrinol. Metab. 2011, 96, 53-58. [CrossRef]

18. Anglin, R.E.; Samaan, Z.; Walter, S.D.; McDonald, S.D. Vitamin D deficiency and depression in adults: Systematic review and meta-analysis. Br. J. Psychiatry 2013, 202, 100-107. [CrossRef] [PubMed]

19. Feldman, D.; Krishnan, A.V.; Swami, S.; Giovannucci, E.; Feldman, B.J. The role of vitamin D in reducing cancer risk and progression. Nat. Rev. Cancer 2014, 14, 342-357. [CrossRef] [PubMed]

20. McCullough, M.L.; Zoltick, E.S.; Weinstein, S.J.; Fedirko, V.; Wang, M.; Cook, N.R.; Eliassen, A.H.; Zeleniuch-Jacquotte, A.; Agnoli, C.; Albanes, D.; et al. Circulating vitamin D and colorectal cancer risk: An international pooling project of 17 cohorts. J. Natl. Cancer Inst. 2019, 111, 158-169. [CrossRef] [PubMed]

21. Ginde, A.A.; Mansbach, J.M.; Camargo, C.A., Jr. Association between serum 25-hydroxyvitamin D level and upper respiratory tract infection in the Third National Health and Nutrition Examination Survey. Arch. Intern. Med. 2009, 169, 384-390. [CrossRef]

22. Jovanovich, A.J.; Ginde, A.A.; Holmen, J.; Jablonski, K.; Allyn, R.L.; Kendrick, J.; Chonchol, M. Vitamin D level and risk of community-acquired pneumonia and sepsis. Nutrients 2014, 6, 2196-2205. [CrossRef]

23. Zhang, R.; Li, B.; Gao, X.; Tian, R.; Pan, Y.; Jiang, Y.; Gu, H.; Wang, Y.; Wang, Y.; Liu, G. Serum 25-hydroxyvitamin D and the risk of cardiovascular disease: Dose-response meta-analysis of prospective studies. Am. J. Clin. Nutr. 2017, 105, 810-819. [CrossRef] [PubMed]

24. Gowda, U.; Mutowo, M.P.; Smith, B.J.; Wluka, A.E.; Renzaho, A.M. Vitamin D supplementation to reduce depression in adults: Meta-analysis of randomized controlled trials. Nutrition 2015, 31, 421-429. [CrossRef]

25. Manson, J.E.; Cook, N.R.; Lee, I.M.; Christen, W.; Bassuk, S.S.; Mora, S.; Gibson, H.; Gordon, D.; Copeland, T.; D’Agostino, D.; et al. Vitamin D supplements and prevention of cancer and cardiovascular disease. N. Engl. J. Med. 2019, 380, 33-44. [CrossRef]

26. Ng, K.; Nimeiri, H.S.; McCleary, N.J.; Abrams, T.A.; Yurgelun, M.B.; Cleary, J.M.; Rubinson, D.A.; Schrag, D.; Miksad, R.; Bullock, A.J.; et al. Effect of high-dose vs standard-dose vitamin D3 supplementation on progression-free survival among patients with advanced or metastatic colorectal cancer: The SUNSHINE randomized clinical trial. JAMA 2019, 321, 1370-1379. [CrossRef]

27. Urashima, M.; Ohdaira, H.; Akutsu, T.; Okada, S.; Yoshida, M.; Kitajima, M.; Suzuki, Y. Effect of vitamin D supplementation on relapse-free survival among patients with digestive tract cancers: The AMATERASU randomized clinical trial. JAMA 2019, 321, 1361-1369. [CrossRef]

28. Langlois, P.L.; Szwec, C.; D'Aragon, F.; Heyland, D.K.; Manzanares, W. Vitamin D supplementation in the critically ill: A systematic review and meta-analysis. Clin. Nutr. 2018, 37, 1238-1246. [CrossRef]

29. Martineau, A.R.; Jolliffe, D.A.; Hooper, R.L.; Greenberg, L.; Aloia, J.F.; Bergman, P.; Dubnov-Raz, G.; Esposito, S.; Ganmaa, D.; Ginde, A.A.; et al. Vitamin D supplementation to prevent acute respiratory tract infections: Systematic review and meta-analysis of individual participant data. BMJ 2017, 356, i6583. [CrossRef]

30. Torjesen, I. Evidence does not support vitamin D for reducing respiratory infections, reviews conclude. BMJ 2020, 369 , m2629. [CrossRef]

31. Pathak, K.; Soares, M.J.; Calton, E.K.; Zhao, Y.; Hallett, J. Vitamin D supplementation and body weight status: A systematic review and meta-analysis of randomized controlled trials. Obes. Rev. 2014, 15, 528-537. [CrossRef] [PubMed]

32. Pittas, A.G.; Dawson-Hughes, B.; Sheehan, P.; Ware, J.H.; Knowler, W.C.; Aroda, V.R.; Brodsky, I.; Ceglia, L.; Chadha, C.; Chatterjee, R.; et al. Vitamin D Supplementation and Prevention of Type 2 Diabetes. N. Engl. J. Med. 2019, 381, 520-530. [CrossRef]

33. Lagunova, Z.; Porojnicu, A.C.; Lindberg, F.; Hexeberg, S.; Moan, J. The dependency of vitamin D status on body mass index, gender, age and season. Anticancer Res. 2009, 29, 3713-3720. [CrossRef] [PubMed]

34. Jorde, R.; Sneve, M.; Emaus, N.; Figenschau, Y.; Grimnes, G. Cross-sectional and longitudinal relation between serum 25hydroxyvitamin D and body mass index: The Tromso study. Eur. J. Nutr. 2010, 49, 401-407. [CrossRef] [PubMed]

35. ISTAC: Estadísticas de la Comunidad Autónoma de Canarias. 2020. Available online: http://www.gobiernodecanarias.org/ istac/estadisticas / demografia/ (accessed on 5 April 2021).

36. Sancho Ávila, J.M.; Jesús Riesco Martín, J.; Jiménez Alonso, C.; Sánchez de Cos Escuin, M.C.; Montero Cadalso, J.; López Bartolomé, M. Atlas de Radiación Solar en España Utilizando Datos del SAF de Clima de EUMETSAT; AEMET: Madrid, Spain, 2012. Available online: http://www.aemet.es/documentos/es/serviciosclimaticos/datosclimatologicos/atlas_radiacion_solar/atlas_ de_radiacion_24042012.pdf (accessed on 5 April 2021).

37. Woodford, H.J.; Barrett, S.; Pattman, S. Vitamin D: Too much testing and treating? Clin. Med. 2018, 18, 196-200. [CrossRef]

38. Sanders, K.M.; Stuart, A.L.; Williamson, E.J.; Simpson, J.A.; Kotowicz, M.A.; Young, D.; Nicholson, G.C. Annual high-dose oral vitamin $\mathrm{D}$ and falls and fractures in older women: A randomized controlled trial. JAMA 2010, 303, 1815-1822. [CrossRef] [PubMed]

39. Korgavkar, K.; Xiong, M.; Weinstock, M.A. Review: Higher vitamin D status and supplementation may be associated with risks. Eur. J. Dermatol. 2014, 24, 428-434. [CrossRef]

40. Galior, K.; Grebe, S.; Singh, R. Development of vitamin D yoxicity from overcorrection of vitamin D deficiency: A review of case reports. Nutrients 2018, 10, 953. [CrossRef] 
41. Jiang, W.; Wu, D.B.; Xiao, G.B.; Ding, B.; Chen, E.Q. An epidemiology survey of vitamin D deficiency and its influencing factors. Med. Clin. 2020, 154, 7-12. [CrossRef]

42. Flores, C.; Maca-Meyer, N.; Perez, J.A.; Gonzalez, A.M.; Larruga, J.M.; Cabrera, V.M. A predominant European ancestry of paternal lineages from Canary Islanders. Ann. Hum. Genet. 2003, 67, 138-152. [CrossRef]

43. Terushkin, V.; Bender, A.; Psaty, E.L.; Engelsen, O.; Wang, S.Q.; Halpern, A.C. Estimated equivalency of vitamin D production from natural sun exposure versus oral vitamin D supplementation across seasons at two US latitudes. J. Am. Acad. Dermatol. 2010, 62, e921-e929. [CrossRef] [PubMed]

44. Petersen, B.; Wulf, H.C.; Triguero-Mas, M.; Philipsen, P.A.; Thieden, E.; Olsen, P.; Heydenreich, J.; Dadvand, P.; Basagana, X.; Liljendahl, T.S.; et al. Sun and ski holidays improve vitamin D status, but are associated with high levels of DNA damage. J. Investig. Dermatol. 2014, 134, 2806-2813. [CrossRef] [PubMed]

45. Young, A.R.; Narbutt, J.; Harrison, G.I.; Lawrence, K.P.; Bell, M.; O’Connor, C.; Olsen, P.; Grys, K.; Baczynska, K.A.; RogowskiTylman, M.; et al. Optimal sunscreen use, during a sun holiday with a very high ultraviolet index, allows vitamin D synthesis without sunburn. Br. J. Dermatol. 2019, 181, 1052-1062. [CrossRef]

46. Klingberg, E.; Olerod, G.; Konar, J.; Petzold, M.; Hammarsten, O. Seasonal variations in serum 25-hydroxy vitamin D levels in a Swedish cohort. Endocrine 2015, 49, 800-808. [CrossRef] [PubMed]

47. Giustina, A.; Bouillon, R.; Binkley, N.; Sempos, C.; Adler, R.A.; Bollerslev, J.; Dawson-Hughes, B.; Ebeling, P.R.; Feldman, D.; Heijboer, A.; et al. Controversies in vitamin D: A statement from the third international conference. JBMR Plus 2020, 4. [CrossRef] [PubMed]

48. WHO Scientific Group on the Prevention and Management of Osteoporosis. Prevention and Management of Osteoporosis: Report of a WHO Scientific Group; World Health Organization: Geneva, Switzerland, 2003. Available online: https://apps.who.int/iris/ handle/10665/42841 (accessed on 5 April 2021).

49. Chapuy, M.C.; Preziosi, P.; Maamer, M.; Arnaud, S.; Galan, P.; Hercberg, S.; Meunier, P.J. Prevalence of vitamin D insufficiency in an adult normal population. Osteoporos. Int. 1997, 7, 439-443. [CrossRef] [PubMed]

50. Steingrimsdottir, L.; Gunnarsson, O.; Indridason, O.S.; Franzson, L.; Sigurdsson, G. Relationship between serum parathyroid hormone levels, vitamin D sufficiency, and calcium intake. JAMA 2005, 294, 2336-2341. [CrossRef]

51. Heaney, R.P. The Vitamin D requirement in health and disease. J. Steroid Biochem. Mol. Biol. 2005, 97, 13-19. [CrossRef] [PubMed]

52. Wu, F.; Wills, K.; Laslett, L.L.; Oldenburg, B.; Seibel, M.J.; Jones, G.; Winzenberg, T. Cut-points for associations between vitamin D status and multiple musculoskeletal outcomes in middle-aged women. Osteoporos. Int. 2017, 28, 505-515. [CrossRef] [PubMed]

53. LeBoff, M.S.; Murata, E.M.; Cook, N.R.; Cawthon, P.; Chou, S.H.; Kotler, G.; Bubes, V.; Buring, J.E.; Manson, J.E. VITamin D and OmegA-3 TriaL (VITAL): Effects of Vitamin D Supplements on Risk of Falls in the US Population. J. Clin. Endocrinol. Metab. 2020, 105. [CrossRef]

54. Scragg, R.; Waayer, D.; Stewart, A.W.; Lawes, C.M.M.; Toop, L.; Murphy, J.; Khaw, K.T.; Camargo, C.A., Jr. The Vitamin D Assessment (ViDA) Study: Design of a randomized controlled trial of vitamin D supplementation for the prevention of cardiovascular disease, acute respiratory infection, falls and non-vertebral fractures. J. Steroid Biochem. Mol. Biol. 2016, 164, 318-325. [CrossRef]

55. Manson, J.E.; Brannon, P.M.; Rosen, C.J.; Taylor, C.L. Vitamin D deficiency-Is there really a pandemic? N. Engl. J. Med. 2016, 375, 1817-1820. [CrossRef]

56. Pittas, A.; Dawson-Hughes, B.; Staten, M. Vitamin D supplementation and prevention of type 2 diabetes. Reply. N. Engl. J. Med. 2019, 381, 1785-1786. [CrossRef]

57. Manios, Y.; Moschonis, G.; Hulshof, T.; Bourhis, A.S.; Hull, G.L.J.; Dowling, K.G.; Kiely, M.E.; Cashman, K.D. Prevalence of vitamin D deficiency and insufficiency among schoolchildren in Greece: The role of sex, degree of urbanisation and seasonality. Br. J. Nutr. 2017, 118, 550-558. [CrossRef]

58. Chailurkit, L.; Aekplakorn, W.; Ongphiphadhanakul, B. Serum C3 epimer of 25-hydroxyvitamin D and its determinants in adults: A national health examination survey in Thais. Osteoporos. Int. 2015, 26, 2339-2344. [CrossRef] [PubMed]

59. Gallagher, J.C. Vitamin D and aging. Endocrinol. Metab. Clin. N. Am. 2013, 42, 319-332. [CrossRef] [PubMed]

60. Farrell, C.J.; Martin, S.; McWhinney, B.; Straub, I.; Williams, P.; Herrmann, M. State-of-the-art vitamin D assays: A comparison of automated immunoassays with liquid chromatography-tandem mass spectrometry methods. Clin. Chem. 2012, 58, 531-542. [CrossRef] [PubMed]

61. Volmer, D.A.; Mendes, L.R.; Stokes, C.S. Analysis of vitamin D metabolic markers by mass spectrometry: Current techniques, limitations of the "gold standard" method, and anticipated future directions. Mass. Spectrom. Rev. 2015, 34, 2-23. [CrossRef]

62. Seida, J.C.; Mitri, J.; Colmers, I.N.; Majumdar, S.R.; Davidson, M.B.; Edwards, A.L.; Hanley, D.A.; Pittas, A.G.; Tjosvold, L.; Johnson, J.A. Clinical review: Effect of vitamin D3 supplementation on improving glucose homeostasis and preventing diabetes: A systematic review and meta-analysis. J. Clin. Endocrinol. Metab. 2014, 99, 3551-3560. [CrossRef] [PubMed] 